\title{
NEOGENE VOLCANISM IN GUTÂI MTS. (EASTERN CARPATHIANS): A REVIEW
}

\author{
MARINEL KOVACS \& ALEXANDRINA FÜLÖP*
}

\begin{abstract}
Two types of volcanism developed in Gutâi Mts. (inner volcanic chain of Eastern Carpathians): a felsic, extensional/"back-arc" type and an intermediate, arc type.

The felsic volcanism of explosive origin, consisting of caldera-related rhyolitic ignimbrites and resedimented volcaniclastics, had taken place during Early-Middle Badenian and Early Sarmatian.

The intermediate volcanism, consisting of extrusive (effusive and explosive) and intrusive activity, had developed during Sarmatian and Pannonian (13.4-7.0 Ma). It is represented by typical calc-alkaline series, from basalts to rhyolites. Lava flows of basaltic andesites and andesites are predominant, often emplaced in subaqueous environment. Extrusive domes, mainly composed of dacites, are associated to the andesitic volcanic structures.

The intrusive volcanic activity developed contemporaneously with the paroxysm of the intermediate volcanism. The intrusive rocks consist mainly of porphyritic aspects of a compositional series from gabbroes to granodiorites.

The geochemical study on the volcanic rocks shows the calc-alkaline character of both felsic and intermediate volcanism and typical subduction zones geochemical signatures for the intermediate one. The felsic volcanism shows affinities with subductionrelated rocks as well. The main petrogenetic process in Gutâi Mts. was crustal assimilation, strongly constrained by trace element and isotope geochemistry.
\end{abstract}

Keywords: Neogene, Gutâi Mts., calc-alkaline volcanism, andesites, extrusive domes, intrusions, subduction, crustal assimilation.

\section{INTRODUCTION}

The volcanism and its products are a special attraction for geologists all over the world. Significant progress in decifering the genesis and evolution of magmatism in the Carpathian-Pannonian Region and its inner volcanic arc have been achieved during the last 10-15 years.

Two main types of volcanism, calc-alkaline and alkaline, have been described as related to the Tertiary geotectonic evolution of the CarpathianPannonian Region (Lexa \& Konecny, 1998). Important contributions on the genesis and the evolution of the volcanism in the Romanian Eastern Carpathians have recently been published by Seghedi et al. (1995) and Mason et al. (1996, 1998).

\footnotetext{
* North University Baia Mare, Faculty of Mineral Resources and Environment, 62/A, Victor Babeş street, Baia Mare 4800
} 
The study of volcanic rocks in the Gutâi Mts. have been constituing the goal of many researchers. Important data concerning the petrography of volcanic rocks and the evolution of volcanism have been published by Rădulescu (1958), lanovici et al. (1961), Rădulescu \& Borcoş (1969), Giuşcă et al. (1973), Borcoş et al. (1973). According to these authors, volcanic activity in the Gutâi Mts. had developed from Badenian to Upper Pliocene, during three main cycles and several eruption phases.

Edelstein et al. $(1978,1980)$ attempted a new approach to the development of the volcanic activity according to geographic units, volcanic subunits (e.g. the geologic map of Oaş-Țibleş Mts., scale 1: 25000, 1980), abandoning the idea of volcanic cycles and phases.

Recent geochronological data published by Edelstein et al. (1992 b, 1993), Pécskay et al. (1994, 1995 b), Kovacs et al. (1997 b) and Fülöp (2001) have essentially changed the interpretations concerning the evolution of volcanism in Gutâi Mts. The Pontian and Pliocene ages, previously supported by biostratigraphy and the relationships between volcanics, are not confirmed. Despite the disagreement between relative and radiogenic ages on volcanics, radiometric dating ( $\mathrm{K} / \mathrm{Ar}$ and $\mathrm{Ar} / \mathrm{Ar}$ ) on epithermal mineralizations associated to volcanics, published by Lang et al. (1994) and Kovacs et al. (1997 b), is consistent with radiometric dating of volcanic rocks. The succession of magmatic rocks, reflected by the new map of the Oaş-Gutâi-Țibleş Mts. (Gabor et al., 1999) is therefore in accordance with the new geochronological data.

Geochemical data on volcanic rocks have previously been published by Rădulescu (1958), Giuşcă et al. (1973), Borcoş et al. (1973, 1979), Lang (1976). The petrogenetic interpretations lack the connection with the geotectonic evolution of the area.

Numerous petrographical and petrochemical data on the volcanic rocks from Gutâi Mts. have been achieved by the specialists working at IPEG Maramureş during 1980-1995 and they may be found in numerous studies and reports preserved in the archive department of the company. Some of these data have been published by Kovacs et al. (1987 a, b), Edelstein et al. (1992 a), Kovacs et al. (1992).

Volcanological data concerning a proper, genetical definition of volcanic products and an attempt to identify the volcanic structures have been presented and partly published by Fülöp \& Kovacs (1996, 2000), Fülöp (2001, 2002 a, b), Kovacs (2002).

Performing and interpreting the high quality geochemical (trace and rare earth elements) and isotope $(\mathrm{Sr}, \mathrm{Nd}, \mathrm{Pb}$ ) analyses have had a major role in identifying the petrogenetic processes in Gutâi Mts. The data have recently been published by Kovacs $(2001,2002)$ and Fülöp (2001). The intermediate volcanism of Gutâi Mts. has been defined as a typical subduction zone-related (arc-type) with an upper mantle (subduction components-enriched mantle wedge) source for the parental magmas (Kovacs, 2001, 2002).

This paper aims at presenting the state of the art on the knowledge regarding the Neogene volcanism of Gutâi Mts.

4 


\section{GEOLOGICAL SETTING}

Gutâi Mts. belong to the Eastern Carpathians Neogene-Quaternary volcanic chain. It has been built up in connection with the Tertiary geotectonic evolution of the Carpathian-Pannonian Region. The post-collisional magmatism related to Miocene subduction of the European Plate beneath the two microplatesAlcapa and Tisza-Dacia/Tisia (Csontos, 1995; Seghedi et al., 1998) - had built up the Eastern Carpathians volcanic arc. Back-arc extensions in the Intracarpathian area/Pannonian Basin were responsible for the calc-alkaline predominant felsic volcanism (Csontos, 1995; Nemčok et al., 1998).

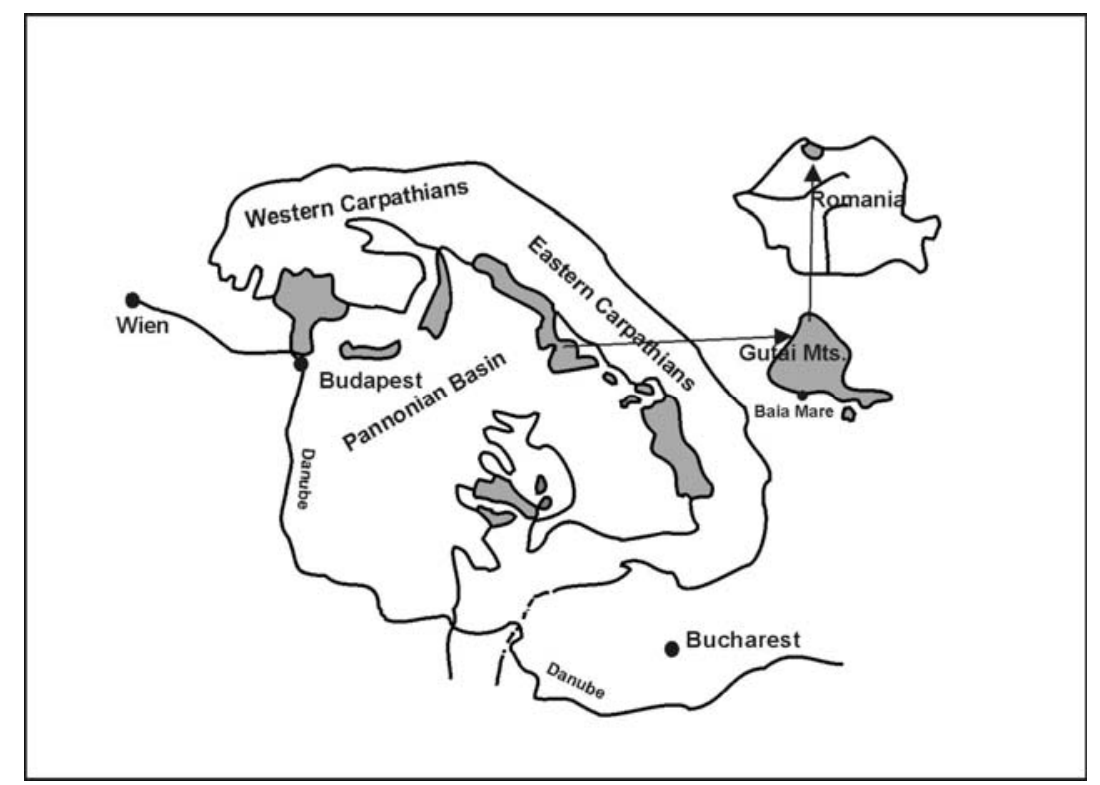

Fig. 1. Sketch of the Carpathian-Pannonian Region and the location of Gutâi Mts.

Gutâi Mts. are located on the northern side of the major transcrustal fault Cârlibaba-Carei which probably represents the extension of the Mid-Hungarian Line (considered as the boundary between Alcapa and Tisza-Dacia microplates, according to Csontos \& Nagymarosy (1998).

The pre-Neogene basement units of the volcanic area consist of Precambrian-Paleozoic metamorphic rocks belonging to the Inner and Median Dacides (Săndulescu, 1984) and Senonian-Oligocene flysch type deposits as overthrust units (outcropping in the south-eastern part of Gutâi Mts.) belonging to Pienides (Săndulescu, 1984; Săndulescu et al., 1993).

The Neogene sedimentary cover is represented by Badenian-Pannonian deposits outcropping in basins adiacent to volcanic area (Oaş, Baia Mare, Maramureş Basins) and some intravolcanic basins. 


\section{VOLCANIC ACTIVITY}

Two main compositional types of volcanism had developed in the Carpathian-Pannonian Region during Neogene and Quaternary: (1) a calc-alkaline volcanism consisting of both felsic (extensional/back-arc type) and intermediate (extensional/back-arc and arc-types) compositions, and (2) an alkaline volcanism (Lexa et al., 1993; Lexa \& Konečny, 1998). In the Eastern Carpathians, felsic calcalkaline volcanism had preceded the intermediate arc-type one. (Pécskay et al., 1995 b).

Two different approaches on the systematization of volcanism in Gutâi Mts. had previously been achieved. Rădulescu \& Borcoş (1969), Giuşcă et al. (1973), Borcoş et al. $(1972,1973)$ had generally described a main stratovolcanic type of volcanism, developed in three cycles and several eruption phases, from Badenian (volcanism of the first cycle) to Upper Pliocene (the next two cycles). Edelstein et al. $(1978,1982)$ had grouped the whole volcanics from Gutâi Mts. into two formations: the "Rhyodacitic Formation" including the Badenian acidic rocks and the "Andesitic Formation" including the Sarmatian-Pliocene volcanic rocks.

From the view point of geotectonic setting, compositional features and according to the volcanic activity systematization in the Carpatho-Pannonian Region (Lexa et al., 1993; Pécskay et al., 1995; Lexa \& Konečny, 1998) and to the recent data regarding the relationships between magmatism ang geotectonic in Gutâi Mts. (Kovacs, 2001, 2002; Kovacs \& Fülöp, 2001) two main types of volcanism have been defined:

- a felsic calc-alkaline extensional, "back-arc" type, including the previously called "Rhyodacitic Formation";

- $\quad$ an intermediate calc-alkaline arc-type representing the main volcanic activity and including the previously considered Sarmatian-Pliocene volcanics.

\section{Evolution of the volcanism}

The felsic calc-alkaline volcanism had started around 15.4 Ma ago (Fülöp, 2001) when caldera-related welded rhyolitic ignimbrites and co-ignimbrite ashfall deposits (Fülöp, 2002 a) have been emplaced on the southern border of the mountains. Two different volcaniclastic sequences overlain the ignimbrites, in Ilba area and in Băița area. They were generated by the volcanic activity following the major ignimbrite phase, and the different degree of interaction of the pyroclastic flows and the subaqueous environment. Volcaniclastics of mass-flow origin record progressive dilution underwent by pyroclastic flows or gravitationally collapsed resedimented volcaniclastics. (Fülöp, 2002 b)

The intermediate calc-alkaline volcanism had a complex evolution during Sarmatian and Pannonian times (13.4-7.0 Ma, Pécskay et al., 1995 b).

The Sarmatian volcanic activity (13.4-12.1 Ma, Edelstein et al., 1992 b; Pécskay et al., 1994) is mainly andesitic, consisting of subaqueous pyroxene basaltic andesite lava flows and associated volcaniclastics and a pyroxene dacite extrusive dome, Şatra Hill, in the southern part of Gutâi Mts. (Fig. 2). 
The volcanism developed during Pannonian time had started with an acidic phase developed in the southern part of the area, emplacing dacitic to rhyolitic domes (Fülöp \& Kovacs, 1996) composed of pyroxene dacites (Şindileu dome), quartz- bearing dacites (Ulmoasa dome), quartz-bearing rhyolites (Piatra Albă dome) and biotite dacites/rhyolites (Dăneşti dome-11.6 Ma, according to Edelstein et al., 1992 b).

The acidic phase was followed by the emplacement of quartz-bearing andesite lava flows and subordinate extrusive domes (e. g. Hircea and Poiana Cremenii domes) with associated volcaniclastics in the central-southern part of Gutâi Mts. (11.3-10.5 Ma, Pécskay et al., 1994-Fig. 2)

The paroxistic volcanic phase took place during Early Pannonian (10.9-9.1 Ma, Edelstein et al., 1992 b; Pécskay et al., 1994). Pyroxene basaltic andesite and pyroxene andesite, pyroxene amphibole andesite lava flows and volcaniclastics (mainly hyaloclastites) were emplaced in the central and eastern part of Gutâi Mts. during 10.9-10.0 Ma. There is a wide range of volcaniclastics associated to lavas, from "in situ" and resedimented hyaloclastites to viscous and dilute mass flow volcaniclastics. They prove that most of the volcanism developed subaqueously, triggering both non-explosive and explosive fragmentation of lavas and resedimentation of volcanic debris. The most important volcanic phase developed during 10.6-9.1 Ma time range. It consists of pyroxene basaltic andesite and andesite lava flows and volcaniclastics, widespread in the northern part of the volcanic area. (Fig. 2). In the south-eastern part of Gutâi Mts. (between Baia Sprie and Cavnic towns), the volcanic products of Mogoşa volcano, belonging to the same volcanic phase, are predominant. They consist of pyroxene basaltic andesite lava flows, associated autoclastic breccias, some related intrusions and a pyroxene and amphibole dacite extrusive dome (Valea Morii, Kovacs, 2002).

A composite extrusive dome (Braga-Pleşca Mare) consisting of biotite pyroxene andesites and biotite dacites, (Gabor et al., 1999) occurs in the centralnorthern part of Gutâi Mts. (9.3 Ma, Pécskay et al., 1995 b). The last event of the Pannonian paroxistic phase (9.0 Ma, Edelstein et al., $1992 \mathrm{~b})$ is represented by the biotite andesite extrusive dome (Gutâi Peak, north from Cavnic, Fig. 2).

Important intrusive activity had been associated to the intermediate arctype volcanism of Gutâi Mts. Intrusions of different shapes, sizes and petrographical compositions have been intercepted by boreholes and mining works, at different depth levels, especially in the southern and eastern parts of the volcanic area. In Poiana Botizei zone, eastern part of Gutâi Mts., the great bulk of igneous rocks is represented by outcropping subvolcanic intrusions.

The relationships between intrusions and volcanic products, the petrographical and petrochemical similarities and the new geochronological data (Pécskay et al., 1995 b; Kovacs et al., 1997 b; Pécskay, unpublished) suggest that the intrusive magmatism developed during the evolution of the main volcanic phases. However, only in some cases intrusions may be attached to identified volcanic structures. 


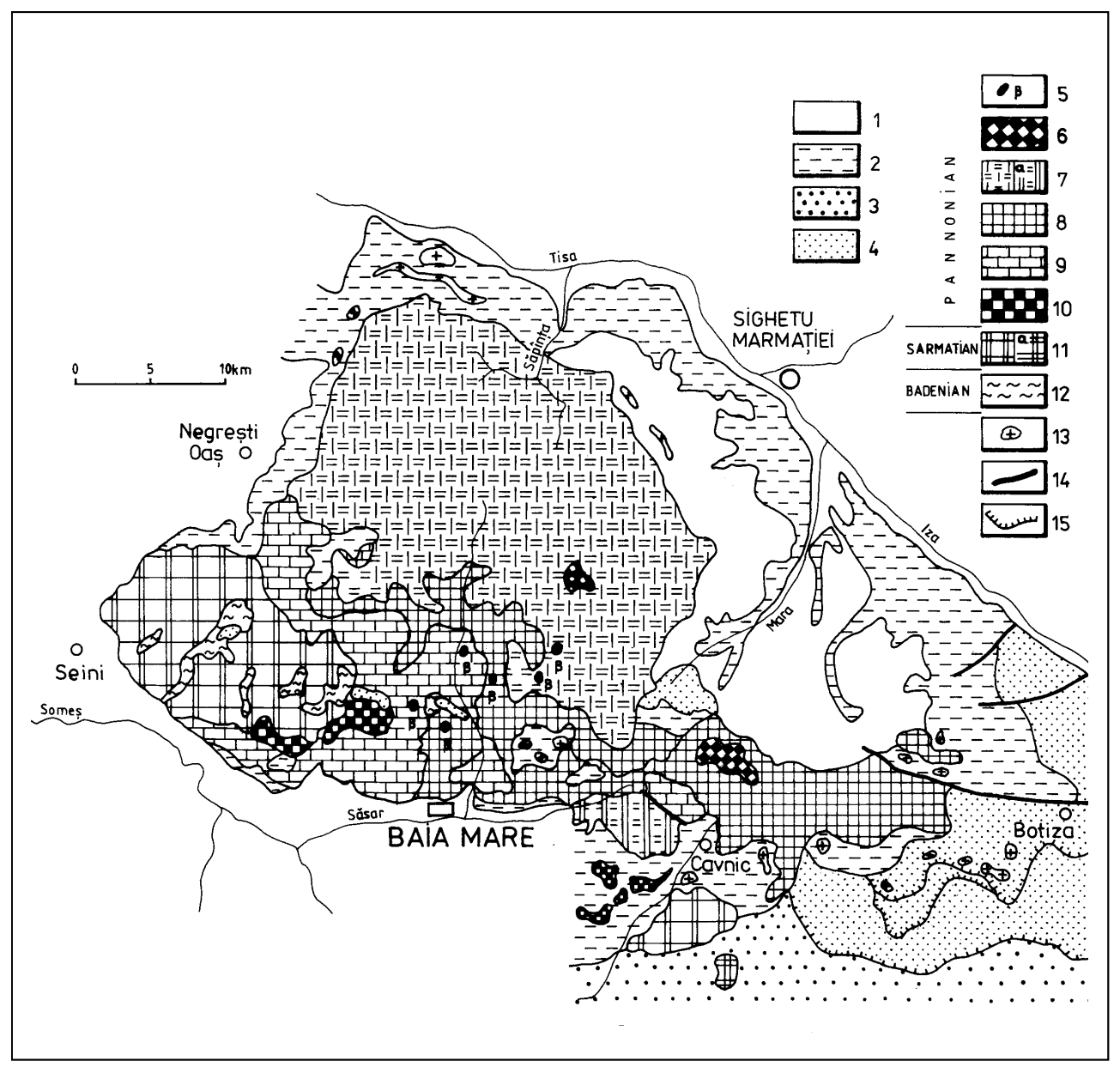

Fig. 2. Simplified geological map of Gutâi Mts. Sedimentary deposits: 1. Quaternary; 2. Neogene; 3. Paleogene-Neogene; 4. Paleogene (Flysch). Volcanic phases: A. PANNONIAN 5. Pyroxene basalts (Firiza type); 6. Biotite andesites and dacites (Braga-Pleşca and Gutâi domes); 7. Pyroxene andesites and basaltic andesites; a. Pyroxene basaltic andesites (Mogoşa volcano); 8. Pyroxene basaltic andesites and andesites and pyroxene-amphibole andesites; 9. Quartz-bearing andesites; 10. Pyroxene dacites, quartz-bearing dacites, biotite dacites/rhyolites (extrusive domes). B. SARMATIAN 11. Pyroxene basaltic andesites and andesites; a. Pyroxene dacites (Şatra dome); C. BADENIAN 12. Rhyolitic ignimbrites; 13. Intrusions; 14. Faults; 15. Overthrusts (modified after Edelstein et al., 1980).

The K-Ar ages of Poiana Botizei subvolcanic intrusive zone (11.3-9.0 Ma, Kovacs et al., $1997 \mathrm{~b}$ ) are similar to those of the main intrusive activity, corresponding to the paroxism of the volcanism.

A late intrusive phase (8.1-7.0 Ma, Edelstein et al., 1993) consisting of small intrusions of calc-alkaline pyroxene basalts (Firiza basalts developed in the central part of the volcanic area, Fig. 2) ceased the magmatism in Gutâi Mts. 


\section{Petrography}

The felsic volcanism is represented by rhyolitic welded lapilli tuffs. Previously called rhyodacites (Borcoş et al., 1973), they have recently been defined as rhyolites, based on chemistry (Fülöp, 2001; Fülöp \& Kovacs, submitted).

The petrographical study of extrusive rocks belonging to the intermediate (arc-type) volcanism shows the presence of the main types of a calc-alkaline series from basalts to rhyolites (Fig. 3 a). Pyroxene andesites and pyroxene basaltic andesites are the predominant rocks.

Quartz-bearing andesites, which are widespread in Gutâi Mts., are represented by different mineralogical and petrographical features: quartz phenocrysts, commonly as corroded crystals with different sizes and in different amounts are present in both basaltic andesites and andesites. The dacites are subordinate; they are the main constituents of extrusive domes but it is worth to notice some petrographic peculiarities: most of the rocks contain exclusively pyroxene as mafic mineral (eg. Şatra, Şindileu domes); amphibole and pyroxene dacites are scarce; the most acidic rocks contain biotite and quartz as predominant phenocrysts, besides amphibole and pyroxene (e.g. Pleşca Mare dacites-68\% $\mathrm{SiO}_{2}$; Dăneşti dacites/rhyolites-68-73\% $\mathrm{SiO}_{2}$ ).

Transitional series of rock types have been determined in some of the volcanic structures: basalts to basaltic andesites in Mogoşa volcano lava flows, dacites to rhyolites in Daneşti extrusive dome (Kovacs, 2002).
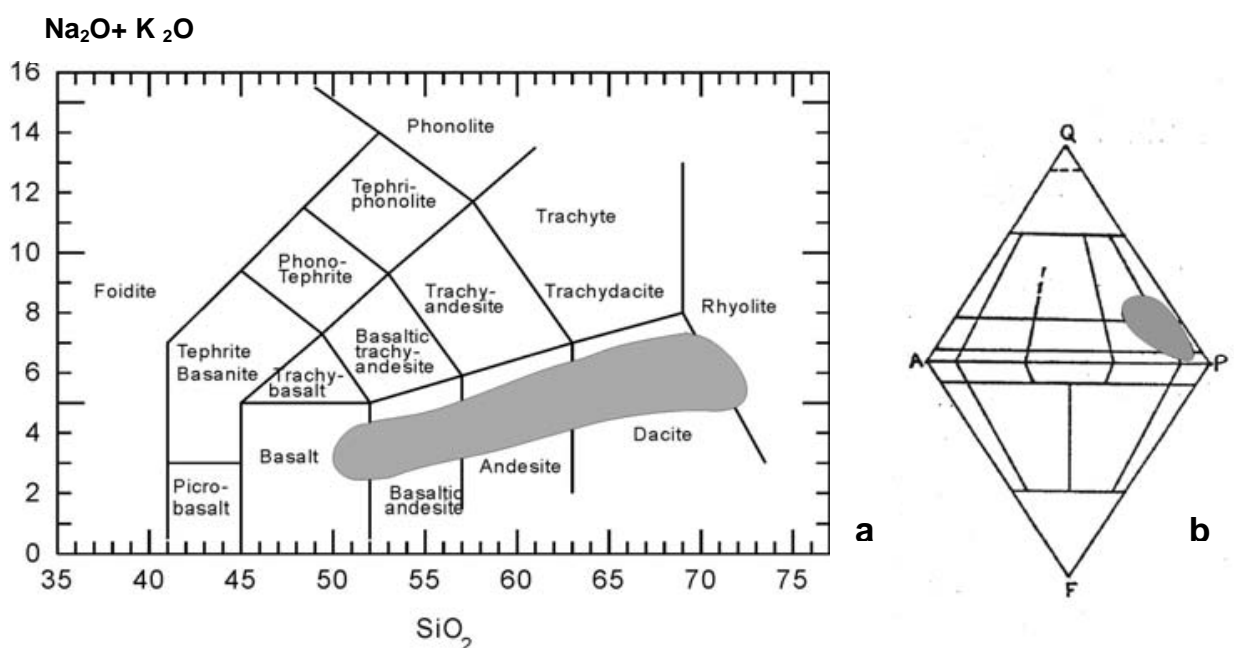

Fig. 3. a. Distribution of the intermediate and felsic volcanics from Gutâi Mts. in TAS diagram.

b. Distribution of intermediate intrusive rocks from Gutâi Mts. in QAPF diagram.

Recent studies on the volcanic rocks from Gutâi Mts. (Kovacs et al., 1997 a; Kovacs, 2002) have pointed out mineralogical and petrographical peculiarities suggesting mixing and mingling processes developed during petrogenesis: 
plagioclase and quartz as xenocrysts, crystal clots of pyroxene in acidic rocks (e. g. Dăneşti biotite dacites/rhyolites), quartz phenocrysts with pyroxene coronas (e. g. biotite andesites from Gutâi extrusive dome), banded pumice (e. g. Breze dacite volcaniclastics).

The intrusive rocks consist of a great variety of structural and compositional types. Porphyritic textures are predominant; transitional textures (microdioritesdiorites, micromonzodiorites-monzodiorites) have been noticed in many intrusive rocks. Typical volcanic rocks such as andesites are frequent within intrusions.

The main rock types specific to intrusive rocks from Gutâi Mts. are represented in the QAPF diagram (Fig. 3 b). Pyroxene microdiorites, quartz diorites and quartz monzodiorites are the most frequent. Biotite and amphibole are more or less associated to felsic rocks such as -microgranodiorites and dacites. The basalts belonging to the Firiza intrusive complex are aphiric with scarce amphibole phenocrysts and typical intergranular/subophitic groundmass.

\section{Geochemistry}

Recent geochemical studies on volcanic rocks from Gutâi Mts. (Kovacs, 2001, 2002; Fülöp, 2001; Fülöp \& Kovacs, this issue) are based on reliable trace element and isotopic analyses run by high quality analytical techniques in geochemical laboratories of Union College-New York, University of London, Henri Poincaré University-Nancy and BRGM-Orléans.

Major, trace element and isotope geochemistry have emphasized important geochemical features for both the felsic and intermediate volcanism. The calcalkaline character of the both types of volcanism is obvious in the AFM diagram (Fig. 4).

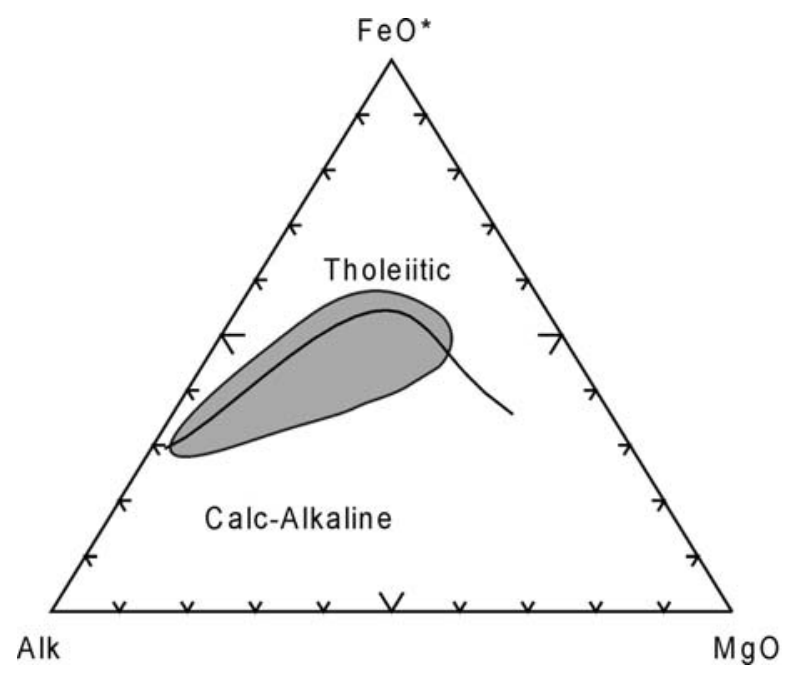

Fig. 4. Distribution of the felsic and intermediate volcanics from Gutâi Mts. in AFM diagram. 
The intermediate volcanics show similarities with the subduction zone related rocks in some discriminant diagrams based on trace elements variation. They fall in the area of the destructive plate margins (subduction zones) field in the Hf/3-Nb/16-Th diagram (Wood, 1980; Fig. 5 a) and in the high Ce/Yb volcanic arcs of destructive plate margins field of the Ba-Nb diagram (Hawkesworth et al., 1994; Fig. 5 b).
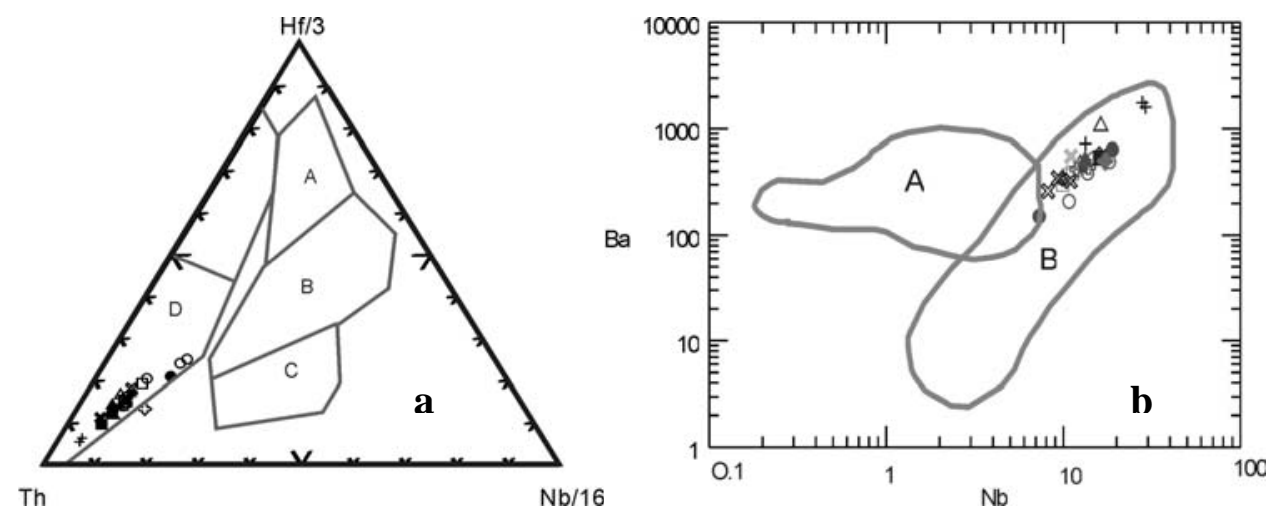

Fig. 5 a. Distribution of intermediate volcanics in Hf/3-Nb/16-Th diagram (Wood, 1980); $A=N M O R B$ field; $B=E M O R B$ field; $C=$ alkaline basalts and intraplate rocks; $D=$ basalts and destructive plate margins rocks.

b. Distribution of the intermediate volcanic rocks in Ba-Nb diagram; $A=L o w C e / Y b$ volcanic arcs field; $B=$ High $\mathrm{Ce} / \mathrm{Yb}$ volcanic arcs field (according to Hawkesworth et al., 1994, with field outlines added).

Typical subduction zones geochemical signatures (LILE and LREE enrichments and HFSE depletions, negative Eu anomaly, negative correlation between ${ }^{87} \mathrm{Sr} /{ }^{86} \mathrm{Sr}$ and ${ }^{143} \mathrm{Nd} /{ }^{144} \mathrm{Nd}$ ratios) have been emphasized for the intermediate volcanics from Gutâi Mts. (Kovacs, 2001, 2002).

The felsic volcanic rocks present affinities with subduction-related volcanic rocks similarly to the intermediate volcanics (Fülöp, 2001; Fülöp \& Kovacs, this issue).

High ${ }^{87} \mathrm{Sr} /{ }^{86} \mathrm{Sr}$ ratio values have been obtained for the intermediate volcanic rocks (Kovacs et al., 1992; Kovacs, 2002). Volcanics with different ages, belonging to different volcanic structures and having a wide range of mineralogical and chemical compositions, show resembling ${ }^{87} \mathrm{Sr} /{ }^{86} \mathrm{Sr}$ ratio values (Fig. $6 \mathrm{a}$ ). Such high values of ${ }^{87} \mathrm{Sr} /{ }^{86} \mathrm{Sr}$ ratios suggest the involvement of crustal assimilation in the petrogenesis of these volcanic rocks.

Comparing these data with those of other typical arc-type volcanics from Eastern Carpathians, similarities are obvious (Fig. 6 b). In both Călimani Mts. and Ukrainian Carpathians (located southeastern and northwestern respectively from Gutâi Mts.), significant crustal assimilation processes have been outlined by Mason et al. (1996) and Seghedi et al. (2001). 

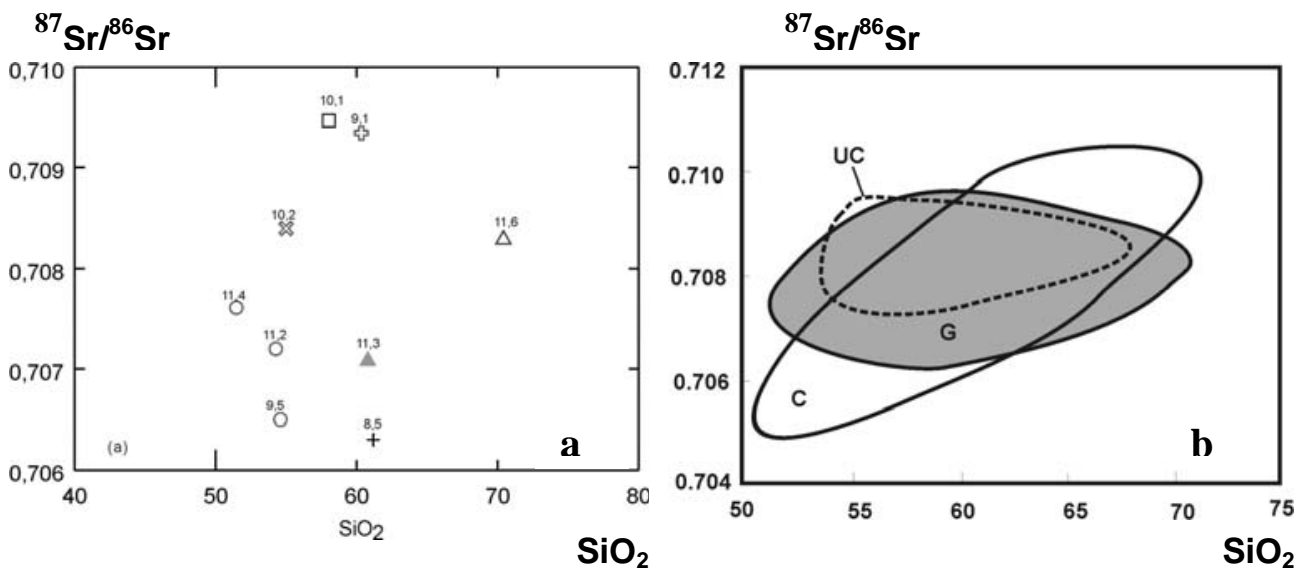

Fig. 6 a. ${ }^{87} \mathrm{Sr}{ }^{\beta 6} \mathrm{Sr}$ ratios variation reported to $\mathrm{SiO}_{2}$ for the intermediate volcanic rocks from Gutâi Mts.; 11.3= KAr ages (according to Edelstein et al., 1992 b; Pécskay et al., 1994; Pécskay unpublished).

b. Comparative data of the ${ }^{87} \mathrm{Sr}{ }^{86} \mathrm{Sr}$ ratios variation reported to $\mathrm{SiO}_{2}$ between Gutâi Mts., Călimani Mts. and Ukrainian Carpathians intermediate arc-type volcanics: $G=$ Gutâi Mts.; C = Călimani Mts. (after Mason et al., 1996); UC = Ukrainian Carpathians (after Seghedi et al., 2001).

\section{CONCLUSIONS}

The recent geochronological, volcanological and petrological data on the volcanism of Gutâi Mts. lead to a new approach and new interpretations of their evolution and petrogenesis. The felsic volcanism had an explosive character being well expressed by caldera-related rhyolitic ignimbrites and resedimented volcaniclastics developed from Early-Middle Badenian to Early Sarmatian.

The intermediate volcanism had a complex evolution during Sarmatian and Pannonian. It is represented by a typical calc-alkaline series, from basalts to rhyolites. Lava flows of basaltic andesites and andesites are predominant, often associated with hyaloclastites and resedimented volcaniclastics. Extrusive domes composed of dacites and acid andesites belong to the andesitic volcanic structures or form individual structures.

Intrusive activity developed contemporaneously with the climax of the volcanism. The intravolcanic and subvolcanic intrusions consist of a great variety of textural and compositional types (from gabbroes to microgranodiorites).

Firiza basalt intrusions represent the last magmatic event in Gutâi Mts.

Both felsic and intermediate volcanism have a calc-alkaline character. Typical subduction-zone geochemical signatures were pointed out for the intermediate volcanism. The felsic volcanism shows affinities with subductionrelated rocks as well. 
Crustal assimilation (added to fractional crystallization) represents the main petrogenetic process of the intermediate arc-type volcanics. Mixing and mingling processes were also involved in the petrogenesis of many volcanics in the Gutâi Mts.

The Neogene volcanic rocks of Gutâi Mts. show many petrographical and geochemical similarities with volcanics belonging to other segments of the subduction related volcanic arc of the Eastern Carpathians, such as Ukrainian Carpathians and Călimani-Gurghiu-Harghita Mts.

\section{REFERENCES}

Borcoş, M., Lang, B., Peltz, S., Stan, N. 1972, The evolution of the Neogen volcanism in the western part of Gutâi Mts. (Negreşti - Seini - Băița). St. Tehn. Ec. I/6, p. 7-37 (in Romanian).

Borcoş, M., Lang, B., Peltz, S., Stan, N. 1973, Volcanisme neogene des Monts Gutâi. Rev. Roum. Géologie, 17/1, p. 81-93.

Borcoş, M., Peltz, S., Stan, N., Udrescu, C., Vasiliu, C. 1979, Petrochemical and geochemical considerations on Neogene volcanics from Gutâi Mts. (II, III, IV). St. tehn. ec. I/16, p. 35-107 (in Romanian).

Csontos, L. 1995, Tertiary tectonic evolution of the Intra - Carpathian area: a review. Acta Vulcanologica, 7(2), p. 1-15.

Csontos, L., Nagymarosy, A. 1998, The Mid-Hungarian line: a zone of repetead tectonic inversions. Tectonophysics, 297, p. 51-71.

Edelstein, O., Răduț, M., Fotopolos, S., Iştvan, D., Dragu, V., Soroiu, M., Pătraşcu, St., Kalmár, I., Hannich, D. 1978, Contributions à la connaissance du déroulement du volcanisme néogène de Monts Oaş - Văratec. Congr. Assoc. Carp. Balk., Kiev, p. 253.

Edelstein, O., Istvan, D., Cojocea, C., Weisz, G., Bernád, A., Stan, D., Kovacs, M. 1980, Geological Map of Oaş-Țibleş Mts., sc.1:25000. Arch. S.C. IPEG Maramureş S.A. Baia Mare (in Romanian).

Edelstein, O., Istvan, D., Bernád, A., Kovacs, M., Stan, D., Fotopolos, S., Cristescu, T., Corcimaru, L., Hannich, D., Popescu, A., Vlaicu, M., Hannich, E. 1982, Complex research geological project in prospecting some igneous structures from OaşȚibleş Mts. during 1982-1985. Arch. SC IPEG Maramureş S.A. Baia Mare (in Romanian).

Edelstein, O., Iştvan, D., Kovacs, M., Bernád, A., Stan, D., Iştvan, E., Gabor, M., Balint, B., Haranth, G., Vârşescu, I. 1992a, Données préliminaires concernant la constitution géologique de la zone Săpânța - Valea Brazilor (Monts de Igniş). Rom J. Petrology, 75, p. 131-143.

Edelstein, O., Bernád, A., Kovacs, M., Crihan, M., Pécskay, Z. 1992 b, Preliminary data regarding the K-Ar ages of some eruptive rocks from Baia Mare Neogene volcanic zone. Rev. Roum. Géologie, 36, p. 45-60. 
Edelstein, O., Pécskay, Z., Kovacs, M., Bernád, A., Crihan, M., Micle, R. 1993, The age of the basalts from Firiza zone, Igniş Mts., East Carpathians, Romania. Rev. Roum. Géologie, 37, p. 37-41, Bucharest.

Fülöp, A. 2001, Sequential analysis of acide pyroclastics from the lower unit of the volcanic complex of Gutâi Mts. Paleovolcanic and Paleosedimentologic reconstructions. Ph D thesis, $163 \mathrm{p}$. University of Bucharest (in Romanian).

Fülöp, A. 2002a, Transport and emplacement of the 15.4 Ma rhyolitic ignimbrites from Gutâi Mts., Eastern Carpathians, Romania. Studia Universitatis Babeş - Bolyai, Geologia, XLVII, 1, p.65-75, Cluj Napoca.

Fülöp, A. 2002b, Facies analysis of volcaniclastic sequence built up above the $15.4 \mathrm{Ma}$ rhyolitic ignimbrites from Gutai Mts., Eastern Carpathians, Studia Universitatis Babeş-Bolyai, Geologia, Special issue, 1, p.199-206, Cluj-Napoca.

Fülöp, A., Kovacs, M. 1996, Pannonian acid volcanism in Gutâi Mts. (East Carpathians, Romania). Volcanological features, magmatological and tectonical significance. In „Plate tectonic aspects of the alpine metallogeny in the Carpatho-Balkan region” Proceedings of the annual meeting, vol. 2, p. 57-67, Sofia.

Fülöp, A., Kovacs, M. 2000, Extrusive volcanism in Oaş-Gutâi Mts. An. Inst. Geol. Rom. 72, Special issue, p. 35, Bucharest.

Fülöp, A, Kovacs, M. this issue, Petrology of Badenian ignimbrites from Gutâi Mts. (Eastern Carpathians). Studia Universitatis Babeş-Bolyai, Geologie, Cluj Napoca.

Gabor, M., Kovacs, M., Edelstein, O., Istvan, D., Bernád, A. 1999, Geological Map of Oaş - Gutâi - Țibleş Mts., sc.1:25000. Arh. S.C. IPEG Maramureş S.A. Baia Mare (in Romanian).

Giuşcă, D., Borcoş, M., Lang, B., Stan, N. 1973, Neogene volcanism and metallogenesis in the Gutâi Mountains: Symposium on Volcanism and Metallogenesis, Bucharest, Guide to Excursion $1 \mathrm{AB}, 50 \mathrm{p}$.

Hawkesworth, C. J., Gallagher, K., Hergt, J. M., McDermot, F. 1994, Destructive plate margin magmatism: Geochemistry and melt generation. Lithos, 33, p. 169-188.

lanovici, V., Giuşcă, D., Manilici, V., Gherasi, N., Jude, R., Gheorghiță, I., Dimitrescu, R. 1961, Baia Mare Guide, Congr. VI G, Carp.-Balc. Geol. Asoc., Bucharest (in Romanian).

Kovacs, M. 2001, Subduction-related magmatism and associated metallogeny in Baia Mare region (Romania), In: Udubaşa and Kovacs (eds.): Geodynamics and ore deposit evolution of the Alpine-Balkan-Carpathian-Dinaride Province, ABCD-GEODE 2001 Workshop Field Guidebook, Rom. J. Mineral Deposits, vol. 79, suppl. 2, p. 3-9.

Kovacs M. 2002, Petrogenesis of the subduction magmatic rocks from central-southeastern area of Gutâi Mountains. Edit. Dacia, 202 p. (in Romanian).

Kovacs, M., Edelstein, O., Iştvan, D. 1987a, Andesites from Oaş-Tibleş Mts.: Considerations regarding their definition and classification based on petrochemical data. St. cerc. Geol. Geofiz., GEOLOGIE, tome 32, p. 12-24, Bucharest (in Romanian).

Kovacs, M., Edelstein, O., Iştvan, D., Pop, N., Bernád, A., Stan, D. 1987b, Petrological data on intrusive bodies from the south-eastern part of Oaş-Tibleş Neogene volcanic chain (between Firiza Valley and Botiza). D. S. Inst. Geol. Geof., 72-73/1, p. 97-119 (in Romanian).

Kovacs, M., Edelstein, O., Iştvan, D., Grabari, G., Stoian, M., Popescu, Gh. 1992, Distribution of REE, K, Rb, Sr and ${ }^{87} \mathrm{Sr} /{ }^{86} \mathrm{Sr}$ ratios in the Neogene andesites of the Igniş-Văratec (Gutâi) Mountains. Rom. J. Petrology, 75, p. 145-159. 


\section{NEOGENE VOLCANISM IN GUTÂI MTS. (EASTERN CARPATHIANS): A REVIEW}

Kovacs, M., Cook, N. J., Radu, D. M. 1997a, Mineral chemistry of the Gutâi volcanics; significance for magmatic evolution. In " $4^{\text {th }}$ National symposium on mineralogy” Abstr. vol., Rom. J. Mineralogy, Vol. 78, Suppl. 1, p. 43-44.

Kovacs, M., Edelstein, O., Gabor, M., Bonhomme, M., Pécskay, Z. 1997b, Neogene magmatism and metallogeny in Oaş-Gutâi-Țibleş Mts.; a new approach based on radiometric datings Rom. J. Mineral Deposits, vol. 78, p. 35-45.

Lang, B. 1976, Mineralogy and Geochemistry of the Neogene Pyroxene Andesites from the Northern Part of the Gutâi Mountains (Romania). An. Inst. Geol. Geofiz., XLIX, p. 153213.

Lang, B., Edelstein, O., Steinitz, G., Kovacs, M., Halga, S. 1994, Ar-Ar dating of adularia - a tool in understanding genetic relations between volcanism and mineralization: Baia Mare area (Gutâi Mountains), northwestern Romania. Economic Geology, Vol. 89, p. 174-180.

Lexa, J., Konečny, V., Kaliciak, M., Hoystricova, V. 1993, Distribucia vulkanitov karpatskopannonskeho regionu v priestore a case. In Rakus, M., Vozar, J. (Eds): Geodinamiki vyvoy a hlbinna Stavba Zapadnych Karpat. GUDS, Bratislava, p. 57-69.

Lexa, J., Konečny, V. 1998, Geodynamic aspects of the Neogene to Quaternary volcanism. In Rakus, M. (Ed): Geodynamic development of the Western Carpathians. GSSR, Bratislava, p. 219-240.

Le Maître R. W., Bateman P., Dudek A., Keller, J., Lameyre Le Bas, M. J., Sabine, P. A., Schmid, R., Sorensen, H., Streckeisen, A., Woolley, A. R., Zanettin, B. 1989, A classification of igneous rocks and a glossary of terms. Blackwell, Oxford, $193 \mathrm{p.}$

Mason, P. R. D., Downes, H., Thirlwall, M. F., Seghedi, I., Szakács, A. D. P., Lowry, D., Mattey, D. 1996, Crustal contamination as a major petrogenetic process in the East Carpathian Neogene and Quaternary continental margin arc, Romania. Journal of Petrology, 37, p. 927-960.

Mason, P. R. D., Seghedi, I., Szakács, A., Downes, H. 1998, Magmatic constraints on geodynamic models of subduction in the Eastern Carpathians, Romania. Tectonophysics, 297, p. 157-176.

Nemčok, M., Pospisil, L., Lexa, J., Donelick, R.A. 1998, Tertiary subduction and slab breakoff model of the Carpathian-Pannonian region. Tectonophysics, 295, p. 307-340.

Pécskay, Z., Edelstein, O., Kovacs, M., Bernád, A., Crihan, M. 1994, K-Ar age determination of Neogene volcanic rocks from the Gutâi Mts. (Eastern Carpathians, Romania). Geologica Carpathica, 45, 6, p. 357-363.

Pécskay, Z., Edelstein, O., Seghedi, I., Szakács, A., Kovacs, M., Crihan, M., Bernád, A. 1995b, K-Ar datings of Neogene-Quaternary calc-alkaline volcanic rocks in Romania. Acta Vulcanologica, 7 (2), p. 53-62.

Rădulescu, D. 1958, Petrographical study of the igneous formations from Seini-llba-Nistru (Baia Mare) region. An. Com. Geol., XXXI (in Romanian).

Rădulescu, D., Borcoş, M. 1969, Apércu général sur l'evolution du volcanisme néogene en Roumanie. Ann. Com. Géol. Roum.XXXVI, 177.

Săndulescu, M. 1984, Geotectonics of Romania. Editura Tehnică, Bucureşti, 336p. (in Romanian).

Săndulescu, M., Visarion, M., Stănică, D., Stănică, M., Atanasiu, L. 1993, Deep structure of the Inner Carpathians in the Maramureş-Tisa zone (East Carpathians). Rom. J. Geophysics, 16, p. 67-76. 
MARINEL KOVACS, ALEXANDRINA FÜLÖP

Seghedi, I., Szakács, A., Mason, P. R. D. 1995, Petrogenesis and magmatic evolution in the East Carpathian Neogene volcanic arc (Romania). Acta Vulcanologica, 7(2), p. 135144.

Seghedi, I., Balintoni, I., Szakács, A. 1998, Interplay of tectonics and Neogene post-collisional magmatism in the intracarpathian region Lithos, 45, p. 483-499.

Seghedi, I., Downes, H., Pécskay, Z., Thirlwall, M., Szákacs, A., Prychodko, M., Mattey, D. 2001, Magmagenesis in a subduction-related post-collisional volcanic arc segment: the Ukrainian Carpathians. Lithos 57, p. 237-262. 